
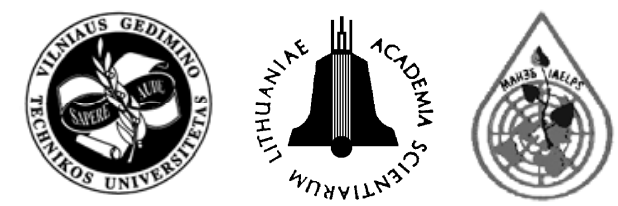

JOURNAL OF ENVIRONMENTAL ENGINEERING AND LANDSCAPE MANAGEMENT

\title{
SOLAR RADIATION ENERGY PULSATIONS IN A PLANT LEAF
}

\author{
Algimantas Sirvydas ${ }^{1}$, Vidmantas Kučinskas ${ }^{2}$, Paulius Kerpauskas ${ }^{3}$, \\ Jūratė Nadzeikiené $\dot{4}^{4}$ Albinas Kusta ${ }^{5}$ \\ Lithuanian University of Agriculture, Studentu g. 11, LT-53361 Akademija, Kauno r., Lithuania \\ E-mail: ${ }^{3}$ paulius.kerpauskas@lzuu.lt (corresponding author)
}

Submitted 11 Dec. 2008; accepted 20 Mar. 2010

\begin{abstract}
Solar radiation energy is used by vegetation, which predetermines the existence of biosphere. The plant uses 1$2 \%$ of the absorbed radiant energy for photosynthesis. All the remaining share of the absorbed energy, accounting for 99$98 \%$, converts into thermal energy in the plant leaf. At the lowest wind under natural surrounding air conditions, plant leaves change their position with respect to the Sun. An oscillating plant leaf receives a variable amount of solar radiation energy, which causes changes in the balance of plant leaf energies and a changing emission of heat in the leaf. The analysis of solar radiation energy pulsations in the plant leaf shows that when the leaf is in the edge positions of angles $10^{\circ}, 20^{\circ}$ and $30^{\circ}$ with respect to the Sun, $1.5 \% ; 6 \%$ and $13 \%$ less of radiation energy reach the leaf, respectively. During periodic motion, when the amplitude of leaf oscillation is no bigger than $10^{\circ}$, the plant surface receives up to $1.6 \%$ less of solar radiation energy within a certain period of time, and when the amplitude of oscillation reaches $30^{\circ}$ up to $14 \%$ less of solar radiation energy reach the leaf surface. The total amount of radiant energy received during pulsations of solar radiation energy is not dependent on the frequency of oscillation in the same interval of time. Temperature pulsations occur in the leaf due to solar radiation energy pulsations when the plant leaf naturally changes its position with respect to the Sun.
\end{abstract}

Keywords: Solar energy, energy flux, plant leaf, energy balance, pulsations, frequency of oscillation, leaf temperature.

\section{Introduction}

Solar radiation energy is used by vegetation, which predetermines the existence of biosphere. The plant uses 1$2 \%$ of the absorbed radiant energy for photosynthesis. All the remaining share of the absorbed energy, accounting for 99-98\%, converts into a form of thermal energy in the plant leaf. Plants absorb $80-85 \%$, reflect around $10 \%$ and pass through leaves $5-10 \%$ of visible sunlight A green leaf selectively absorbs solar radiation energy. In the area of UV radiation, in in the area of visible and farinfrared rays $(>1 \mu \mathrm{m})-80-95 \%$, in the area of nearinfrared rays $(0.7-1.0 \mu \mathrm{m})-5-15 \%$. In the area of visible rays, the blue and red rays show higher absorption (90$95 \%)$ than the green rays (50-80\%). Rays of the infrared ray $(>1 \mu \mathrm{m})$ area are mainly absorbed by water contained in plant tissues. Under natural environmental conditions, the plant leaf absorbs $35-50 \%$ of the integral $(0.3-4.0$ $\mu \mathrm{m})$ radiation of the Sun. The major part (75-85\%) is absorbed from the Sun's radiation of wave length $(0.38-$ $0.72 \mu \mathrm{m}$ ), which concentrates around $45-50 \%$ of the Sun's integral radiation. The effect of radiation on plants depends on a wave length (spectrum) and radiation density $\mathrm{W} / \mathrm{m}^{2}$. The essential purpose of light is the transformation of its energy to carbon compounds. In a year, vegetation of the Earth assimilates around 640 bn tons of carbon dioxide and emits around 500 bn tons of free oxygen thus reducing environmental pollution (Ількун 1967; Šlapakauskas 2006).
The plant together with the surrounding environment forms an integral undivided system - an agrofit environment. The main factors of forecasting and assessing the effect of the agrofit environment on the plant include light (radiant energy), temperature (heat) and moisture (water). These three environmental factors (as the thermal energy factors), predetermining the conditions of plant's productivity, minimum existence and death, can be analysed by the method of the plant's balance of energies through the employment of the laws of thermodynamics. According to the first law of thermodynamics, one form of energy may transform into another one. In this transformation energy is neither destroyed nor created.

H. T. Browh and F. Escombe were the first to employ the method of the balance of energies in vegetation research in 1905. Later the method was applied in many research papers. The balance of plant's energies was analysed with the aim to evaluate its relationship with physiological processes occurring in the plant, i.e. transpiration, photosynthesis and convective heat exchange (Ruseckas 2002; Ількун 1967; Sirvydas, Kerpauskas 2006) or theoretically substantiate or advance technological processes (Čèsna et al. 2000; Sirvydas et al. 2006; Kajalavičius 1992; Kerpauskas et al. 2006).

Plant leaves are malleable. At the lowest wind under natural ambient air conditions, plant leaves change their position with respect to the Sun. An oscillating plant leaf receives a variable amount of solar radiation energy, which changes the balance of plant leaf energies, as well as changing heat emission in the leaf, respectively. It is 
common knowledge that changing radiation exposure activates processes occurring in the plant leaf (Hayashi 2001; Stašauskaitė 1995; Lafta, Lorenzen 1995; Šlapakauskas ir Duchovskis 2008).

The aim of research is to analyse the balance of energies in the plant leaf in order to determine the pulsations of the Sun's radiant energy, which are caused by plant leaf oscillations with respect of the Sun.

\section{The methods of research}

The method of the balance of energies is employed to theoretically analyse energy and humidity environmental exchange processes. According to this method, any moment of the plant's existence is subject to the equality between the energy received, accumulated, used for biological processes and transferred to the environment (in a form of heat and water vapour), i.e. $\Sigma Q=0$ (Sirvydas et al. 2000; Herve et al. 2002; Venslauskas 1996).

When analysing the dependence of plant leaf temperature pulsations on a single factor, i.e. leaf oscillations with respect of the Sun, the processes of energy metabolism, occurring in the plant leaf, are schematised.

\section{Investigation results}

The equation of the balance of energies is applied for the plant leaf. No condensation of humidity present in the air is possible on the leaf surface during sunny time of the day and therefore a member of the energy balance, evaluating the condensation of moisture, equals zero and is excluded from the evaluation. A heat flux within leaf stem tissues when the leaf stem's cross-section is small at a low gradient of temperature, thermal conductivity and plant sap flow should also be rejected. Under the mentioned conditions, the equation of the balance of plant energies is as follows:

$$
\pm Q_{1} \pm Q_{2} \pm Q_{3} \pm Q_{4} \pm Q_{5}=0,
$$

where $Q_{1}$ - flux of the Sun's radiation energy absorbed by the plant, J/s; $Q_{2}$ - heat flux, transferred to or received from the environment during convective heat exchange, $\mathrm{J} / \mathrm{s} ; Q_{3}-$ heat flux used for transpiration and transferred to the environment in a form of water vapour, $\mathrm{J} / \mathrm{s} ; Q_{4}-$ heat flux for photochemical reactions in an energy form or other exothermal and endothermic processes occurring in the plant, $\mathrm{J} / \mathrm{s} ; Q_{5}-$ heat flux participating in the process of plant tissue thermal accumulation, $\mathrm{J} / \mathrm{s}$.

The period of research was selected at the constant radiation of the Sun, i.e. $Q_{1}=$ const. For a very short period of time $d \tau$, it is assumed that biological processes occurring in the plant leaf remain stable and use a constant amount of solar energy. Then, the amount of energy used for biological processes in the plant leaf $Q_{4}$ can be expressed as follows:

$$
Q_{4}=n Q_{1}
$$

where $n$ - the coefficient that evaluates the part of the absorbed solar energy, which is used for biological pro- cesses in the plant, $n=0.04-0.05$ (Šlapakauskas 2006; Ількун 1967).

The portion of the absorbed solar energy remaining in the plant leaf will be used for transpiration and convective heat exchange with the environment. Then, at the plant's steady energy metabolism $\left(Q_{5}=0\right)$, the equation of the balance of energies may be as follows:

$$
(1-n) Q_{1}=Q_{2}+Q_{3} \text {. }
$$

It is assumed that in this very short period of time the intensity of transpiration $\left(Q_{3}=\right.$ const $)$ and convective heat exchange $\left(Q_{2}=\right.$ const) remain stable. This can be done using average intensity values of transpiration and convective heat exchange.

The steady energy metabolism in the plant leaf changes with the change of the amount of the Sun's radiation energy received by the leaf. Impacted by the wind, the plant leaf oscillates and respectively receives an alternating amount of the Sun's radiation energy. The plant leaf also receives an alternating amount of the Sun's radiation energy due to a sudden change in cloudiness, ventilation of greenhouses or installation of mobile equipment intended for plant irradiation. In a natural environment, chaotically moving air moves plant leaves. Leaves change their position with respect to the Sun with the change of the leaf position angle $\beta$ (Fig. 1).

When the leaf changes its position from $B$ to $C$ with respect to the Sun (Fig. 1a), the amount of the Sun's radiation energy, absorbed by the leaf, decreases. The reason for decrease of this type of energy is analysed below.

The quantity of the Sun's radiation energy that reaches the leaf surface at the Sun's heat flux density $q_{1}=$ const is directly dependent on the size of the plant leaf surface area $F$ projection to the plane perpendicular to a ray fall direction. Upon assuming that the ray fall direction is perpendicular to the plant leaf plane, the projection of the plant leaf surface area in position $B$ would be $F_{X B}$ (Fig. 1b).

When the plant leaf position changes from B to C, the projection of the plant leaf surface area to the plane perpendicular to the ray fall direction would decrease by value $\Delta F_{x}$ and would be $F_{x C}$, respectively (Fig. $1 \mathrm{~b}$ ). The value $\Delta F_{X}$ shows a decrease in an active surface area of the plant leaf when the leaf position with respect to the Sun changes by angle $\beta$, which is found according to the equation:

$$
\Delta F_{x}=F_{x B}-F_{x C}=F(1-\cos \beta),
$$

where $\Delta F_{x}$ - decrease of an active surface area of the plant leaf when the leaf position with respect to the Sun changes, $\mathrm{cm}^{2} ; F_{x B}, F_{x C}$ - the projection of the plant leaf surface area in positions $B$ and $C$, respectively (Fig. 1b), $\mathrm{cm}^{2} ; F$ - plant leaf area, $\mathrm{cm}^{2} ; \beta$ - the angle rad of the plant leaf position with respect to the Sun.

At such a decrease in the projection of the plant leaf surface area due to the change of the leaf position with respect to the Sun, the amount of heat that reaches the leaf surface when the leaf position changes from $\mathrm{B}$ to $\mathrm{C}$ will also decrease by value $\Delta Q_{1}$. 
When the flux density of the Sun's absorbed energy $q_{1}=$ const, the decrease $\Delta Q_{1}$ of the heat quantity that reaches the leaf surface $Q_{1}$ due to changed plant leaf position by the angle $\beta$ will be expressed by the following dependence:

$$
\begin{aligned}
& \Delta Q_{1}=Q_{1 B}-Q_{1 C}=q_{1} F(1-\cos \beta) \\
& \text { or } \\
& \Delta Q_{1}=Q_{1}(1-\cos \beta),
\end{aligned}
$$

where $\Delta Q_{1}$ - the decrease of the heat flux $Q_{1}$ that reaches the plant leaf surface, $\mathrm{J} / \mathrm{s} ; Q_{1 B}, Q_{1 C}$ - the absorbed flux of the Sun's radiation energy when the plant leaf is in the position $\mathrm{B}$ and $\mathrm{C}$, respectively (Fig. 1 ; b) $\mathrm{J} / \mathrm{s} ; q_{1}-$ flux density of the absorbed solar energy $\mathrm{W} / \mathrm{cm}^{2} \mathrm{~F}$ - plant leaf area, $\mathrm{cm}^{2} ; \beta$ - the angle rad of leaf position with respect to the Sun.

Plant organs and parts are in a constant dynamic equilibrium and therefore a change in plant leaf temperature is described by the change of the balance of energies of the plant organ or any part thereof at a certain moment of time. The plant organ temperature change by value $\Delta t$, as an expression of a dynamic energies balance, manifests itself via the process of thermal accumulation.

The intensity of transpiration $Q_{3}$ and convective heat exchange $Q_{2}$ within a very short elementary period of time $d \tau$ remains constant and, therefore, when leaf temperature changes by value $\Delta t$ the lack of energy is compensated by heat $Q_{5}$ accumulated in the plant leaf.

With the aim to determine a change in the plant leaf temperature, the following equation of the balance of energies is applied for the process in question:

$$
\begin{aligned}
& \Delta Q_{1}=Q_{5} \\
& \text { or } \\
& (1-\cos \beta) Q_{1}=Q_{5} \frac{d(\Delta t)}{d \tau} .
\end{aligned}
$$

The member of the balance of energies equation (1-cos $\beta$ ), expressing a decrease in energy reaching the leaf surface, will change in the course of time depending on the angle size of the leaf position with respect to the Sun.

Quantity of heat $Q_{5}$ accumulated in the plant leaf is expressed by the following equation:

$$
Q_{5}=\rho c V \frac{d(\Delta t)}{d \tau},
$$

where $\rho$ - plant leaf density in $\mathrm{g} / \mathrm{cm}^{3} ; c$ - specific thermal capacity of the plant leaf in $\mathrm{J} /(\mathrm{g} \cdot \mathrm{K}) ; \mathrm{V}$ - plant leaf volume in $\mathrm{cm}^{3} ; \Delta t$ - temperature change in the plant leaf ${ }^{\circ} \mathrm{C}$; $\tau$-time in s.

The following markings will be used in further analysis of the plant leaf temperature change due to pulsations of the Sun's radiation energy at any moment of time:

$$
\begin{aligned}
& t_{0}-t_{a p l}=\vartheta_{0} ; \\
& \Delta t=\vartheta ; \\
& t_{0}-\Delta t-t_{a p l}=\vartheta_{0}-\vartheta,
\end{aligned}
$$

where $t_{0}$ - initial plant leaf temperature ${ }^{\circ} \mathrm{C} ; t_{a p l}$ - ambient temperature ${ }^{\circ} \mathrm{C} ; \Delta t$ - change in plant leaf temperature at a certain moment of time, ${ }^{\circ} \mathrm{C}$.

According to markings (8), the member $Q_{2}$ of the balance of energies equation (3), describing convective heat exchange between the plant leaf and the environment, will be expressed by the following equation:

$$
\begin{aligned}
& Q_{2}=\alpha F\left(t_{0}-t_{a p l}\right)+\alpha F\left(t_{0}-\Delta t-t_{a p l}\right)= \\
& 2 \alpha F \vartheta_{0}-\alpha F \vartheta,
\end{aligned}
$$

where $\alpha$ - the plant leaf's heat transfer coefficient $\mathrm{J} /\left(\mathrm{s} \cdot \mathrm{cm}^{2} \cdot \mathrm{K}\right) ; F$ - the plant leaf area in $\mathrm{cm}^{2}$.

The member $Q_{3}$ of the balance of energies equation (3), also describing the process of transpiration, is expressed by the following equation:

$$
Q_{3}=w r F,
$$

where: $w$ - intensity of transpiration $\mathrm{g} /\left(\mathrm{cm}^{2} \cdot \mathrm{s}\right) ; r$ - heat of evaporation $\mathrm{J} / \mathrm{g}$.

a)

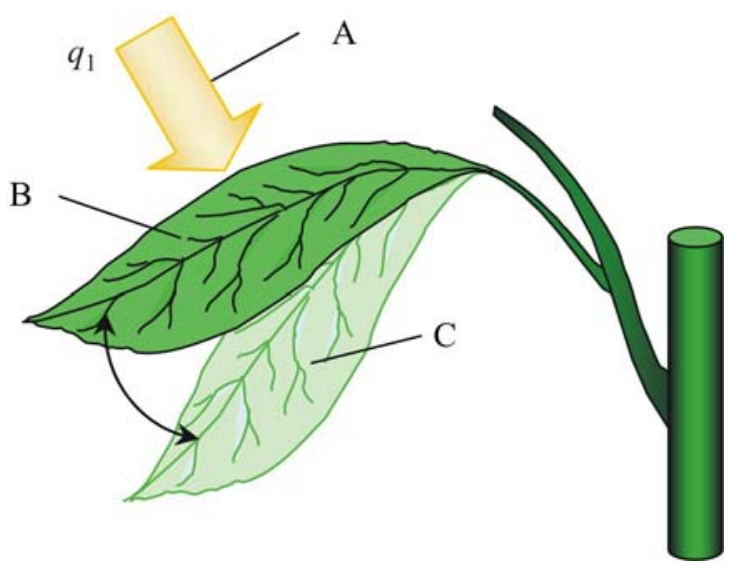

b)

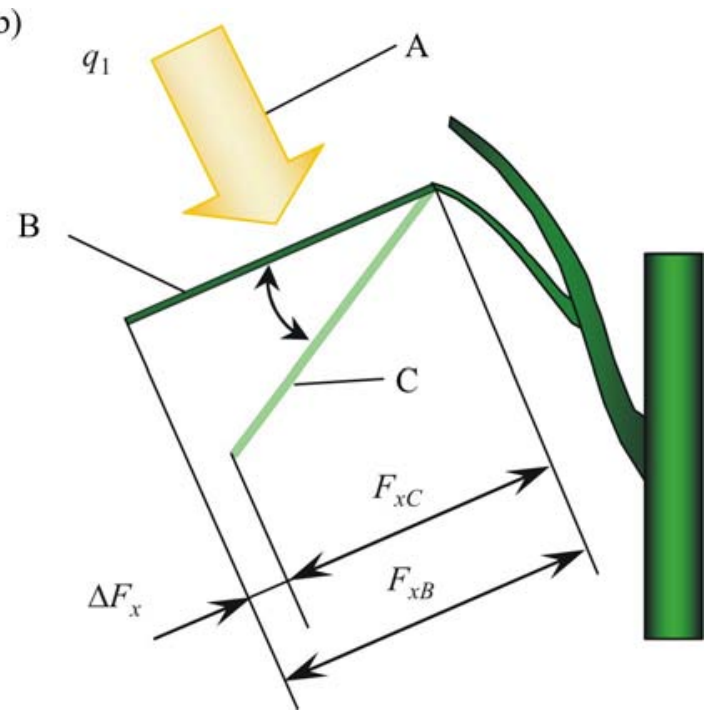

Fig. 1. Chart of changing plant leaf position with respect to the Sun's radiation: A - solar radiation direction; B, C - edge positions of the plant leaf with respect to the Sun; a - plant leaf position changing scheme; $b$ - changes of plant leaf surface projection to the plane perpendicular to ray fall direction 
Considering the fact that the intensity of transpiration $Q_{3}$ and convective heat exchange $Q_{2}$ within the elementary period of time $d \tau$ remains constant, and expressions (9) and (10), the balance of energies equation (3) is changed as follows:

$$
(1-n) Q_{1}=2 \alpha F \vartheta_{0}-\alpha F \vartheta+w r F
$$

The expression (11) shows that the quantity of radiation energy that reaches the leaf surface in a form of heat $Q_{1}$ equals:

$$
Q_{1}=\frac{2 \alpha F \vartheta_{0}-\alpha F \vartheta+w r F}{1-n} .
$$

Consequently, considering the expressions (7), (8) and (12), the balance of energies equation (6) is changed as follows:

$$
\frac{(1-\cos \beta)}{1-n}\left(2 \alpha F \vartheta_{0}-\alpha F \vartheta+w r F\right)=\rho c V \frac{d \vartheta}{d \tau} .
$$

The member $\frac{1-\cos \beta}{1-n}$ of equation (13) is marked by $S$. In terms of physics, this value expresses a decrease in the absorbed solar radiation energy. The decrease of the absorbed solar radiation energy $S$ can be assumed as a constant value at a certain moment $\tau_{\mathrm{i}}$ of the leaf position $C_{\mathrm{i}}$ or as a changing one according to a certain regularity that is predetermined by leaf oscillations.

Upon separating the variables $\vartheta$ and $\tau$ of the equation (13), integrating and turning into algorithms the obtained expression, the following equation is obtained:

$$
2 \vartheta_{0}-\vartheta-\frac{w r}{\alpha}=C \exp \left(\frac{-\alpha F S}{\rho c V} \tau\right) \text {. }
$$

The integration constant $C$ is expressed from the equation (14):

$$
C=\frac{\vartheta-2 \vartheta_{0}-\frac{w r}{\alpha}}{\exp \left(-\frac{\alpha F S}{\rho c V} \tau\right)} .
$$

At the initial period of time when $\tau=0$, temperature difference $\vartheta=0$, and therefore the constant of integration $C$ is equal to:

$$
C=-2 \vartheta_{0}-\frac{w r}{\alpha} .
$$

The solution of the equation (13), i.e. temperature change $\vartheta$, is obtained by entering the constant of integration $C$ in (14):

$$
\vartheta=\left(2 \vartheta_{0}+\frac{w r}{\alpha}\right)\left(1-\exp \left(\frac{-\alpha F S}{\rho c V} \cdot \tau\right)\right) .
$$

Considering the fact that plant leaf volume $V=F \delta$ (where $\delta$ - plant leaf thickness in $\mathrm{cm}$ ) and the introduced markings of temperature (8), the final expression of a temperature change in the plant leaf is obtained:

$$
\Delta t=\left(2\left(t_{0}-t_{a p l}\right)+\frac{w r}{\alpha}\right)\left(1-\exp \left(\frac{-\alpha S}{\rho c \delta} \cdot \tau\right)\right) \text {. }
$$

As the expression (18) shows, the temperature change $\Delta t$ on the surface of the plant leaf depends on a number of parameters: the initial changes of temperatures between the leaf surface and the environment $\left(t_{0}-t_{a p l}\right)$, the intensity of plant transpiration, the heat of evaporation, the heat transfer coefficient, density, specific heat, the coefficient of decrease of the absorbed solar radiation energy $S$, and plant leaf thickness $\delta$. Of the mentioned parameters, changeable ones are the decrease coefficient of the absorbed solar radiation energy $S$, whose value is directly dependent on the change of the leaf position angle $\beta$ with respect to the Sun, and plant leaf thickness. It is common knowledge that the thickness of any plant leaf is not the same within a transverse section (Fig. 2). Therefore, it is probable that different temperature changes $\Delta t_{1}$ and $\Delta t_{2}$ caused by the Sun's radiation energy pulsations occur on the plant leaf surface due to segments of different thicknesses (e.g., $\delta_{1}$ and $\delta_{2}$ ).

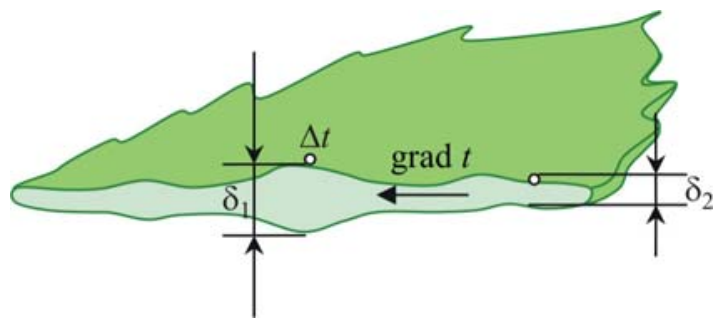

Fig. 2. Plant leaf thickness in a transverse section. Explanations are given in the text

Thus, there emerge a temperature gradient (grad $t$ ) between the mentioned plant leaf segments of different thickness and a temperature difference $\Delta t_{\delta}$, caused by the difference in these thicknesses. Based on the assumption that $\Delta t_{1}>\Delta t_{2}$ and on the expression (18), the difference of temperatures $\Delta t_{\delta}$ between the plant leaf segments of different thicknesses $\delta_{1}$ and $\delta_{2}$ can be expressed as follows:

$$
\begin{aligned}
& \Delta t_{\delta}=\Delta t_{1}-\Delta t_{2}=\left(\left(t_{0}-t_{a p l}\right)+\frac{w r}{2 \alpha}\right) \times \\
& \left(\exp \left(\frac{-2 \alpha S}{\rho c \delta_{2}}\right)-\exp \left(\frac{-2 \alpha S}{\rho c \delta_{1}}\right)\right) \tau .
\end{aligned}
$$

The analysis of the Sun's radiation energy pulsations and the likely dependence of the plant leaf temperature change on the plant position angle $\beta$ offers two cases. In the first case, a decrease in energy reaching the plant surface is measured according to the size of angle $\beta$ at a certain time moment $\tau$ (Fig. 3a).

Under natural conditions, the angle of the leaf position $\beta$ with respect to the Sun may change in time, i.e. $\beta=f(\tau)$. In this case, the change of angle $\beta$ may be described by a certain periodic function (Fig. $3 b$ ).

For the second case in question (Fig. 3b) it is assumed that the plant leaf oscillates in a semicircle trajectory, which can be described by the sine function. In this case, the change of the plant position angle size is described by the following equation:

$$
\beta=\beta_{A} \sin \left(\pi f \tau+\varphi_{0}\right),
$$


where: $\beta_{A}$ - leaf oscillation amplitude, rad; $f$ - leaf oscillation frequency, $\mathrm{s}^{-1} ; \tau$ - time, $\mathrm{s} ; \varphi_{0}-$ initial phase of oscillation (assumed in calculations $\varphi_{0}=0$ ), rad.

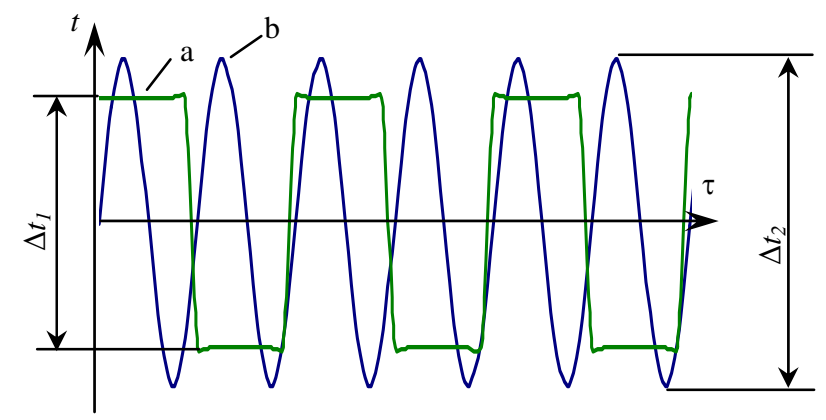

Fig. 3. Case examples of plant leaf position angle $\beta$ change with respect to the Sun's radiation. Explanations are given in the text

As mentioned before, the solution (18) of the equation (13) is directly dependent on the decrease coefficient of the Sun's radiation energy absorbed by its member $S$, which in both cases discussed (Fig. 3a and b) is expressed by the following equations, respectively:

$$
\begin{gathered}
S_{1}=\frac{1-\cos \beta}{1-n}, \\
S_{2}=\frac{1-\cos \left(\beta_{A} \sin \left(\pi f \tau+\varphi_{0}\right)\right)}{1-n} .
\end{gathered}
$$

As the expression (21) shows, the decrease coefficient of the absorbed solar radiation energy $S_{1}$ does not depend on the duration of the plant leaf's being in a certain position. The coefficient $S_{1}$ value is determined by the size of the plant leaf position angle $\beta$.

Values of the decrease coefficient of the absorbed solar radiation energy $S_{1}$, calculated according to the expression (21) are given in Fig. 4.

The analysis of values of the decrease coefficient of the absorbed solar radiation energy $S_{1}$ shows that when the plant leaf is at the angles of $10^{\circ} ; 20^{\circ}$ and $30^{\circ}$ with respect to the Sun, the coefficient $S_{1}$ values are 0.015; 0.06 and 0.13 , respectively. These findings show that when the plant leaf is in the mentioned positions of angle $\beta$ with respect to the Sun, $1.5 \% ; 6 \%$ and $13 \%$ less of radiation energy reach the plant leaf, respectively.

Values of the decrease coefficient of the absorbed solar radiation energy $S_{2}$ that is periodically changing in time depend on the plant leaf oscillation amplitude $\beta_{A}$ and oscillation frequency $f$, whose value is directly dependent on the number of oscillations within a certain period. Calculations were made on the assumption that plant leaf oscillation frequency $f$ is $0,5 \mathrm{~s}^{-1} ; 1 \mathrm{~s}^{-1}$ and $2 \mathrm{~s}^{-1}$, the minimum plant leaf oscillation amplitude $\beta_{A}=10^{\circ}$, and the maximum amplitude $\beta_{A}=30^{\circ}$.

Values of the decrease coefficient of the solar radiation energy $S_{2}$, calculated according to expression (22), when the plant leaf oscillation amplitude $\beta_{A}=10^{\circ}$ and $\beta_{A}=30^{\circ}$, are given in Fig. 5 ( $a$ and b). When the plant oscillation amplitude reaches $30^{\circ}$, values of the decrease coefficient of solar radiation energy $S_{2}$ are up to 8.75 times higher than in the case of the leaf oscillation amplitude of $10^{\circ}$. This shows that when the leaf oscillation amplitude increases three times, a decrease in the amount of solar radiation energy that reaches the plant surface exceeds the increase of the amplitude, i.e. the decrease of radiant energy amount is not directly proportional to the increase of the plant leaf oscillation amplitude. Pulsations of the Sun's radiation energy decrease occur in certain intervals of time depending on the plant leaf oscillation frequency (Fig. 5).

The calculation results of the coefficient $S_{2}$ at different frequencies of the plant leaf show that the total decrease of the radiation energy amount within a certain time interval does not depend on the leaf oscillation frequency. Energy decrease is reflected by the area limited by the coefficient $S_{2}$ function graph, expressing the amount of radiation energy. As Fig. 5 shows, the total radiation energy amount obtained during pulsations of the Sun's radiation energy in $1 \mathrm{~s}$ is the same regardless of the oscillation frequency and therefore does not depend on the oscillation frequency in the same interval of time. The oscillation frequency predetermines the size of energy decrease, i.e. the value of coefficient $S_{2}$ in a certain moment of time.

When the plant leaf periodically oscillates at the amplitude $\beta_{A}=10^{\circ}$, up to $1.6 \%$ less of the Sun's radiation energy reach its surface in a certain time (Fig. 5a). When the plant leaf oscillation amplitude reaches up to $30^{\circ}$, up to $14 \%$ less of the Sun's radiation energy reach the leaf surface in a certain period of oscillation (Fig. 5b).

As the results of the decrease coefficients of the absorbed radiation energy $S_{1}$ and $S_{2}$ show, they will have a direct determinant effect on temperature changes in the plant leaf. Based on the obtained results of these coefficients, the plan is to conduct research on the effect of the Sun's radiation energy pulsations on the plant leaf temperature changes.

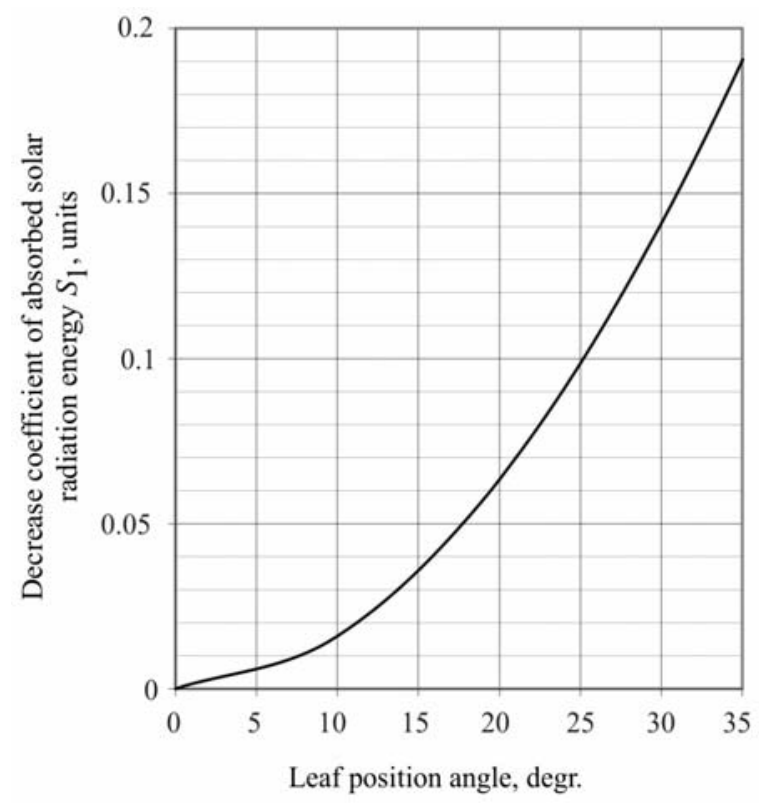

Fig. 4. Dependence of the decrease coefficient of the absorbed solar radiation energy $S_{1}$ on leaf position angle $\beta$ (Fig. 1) 
a)

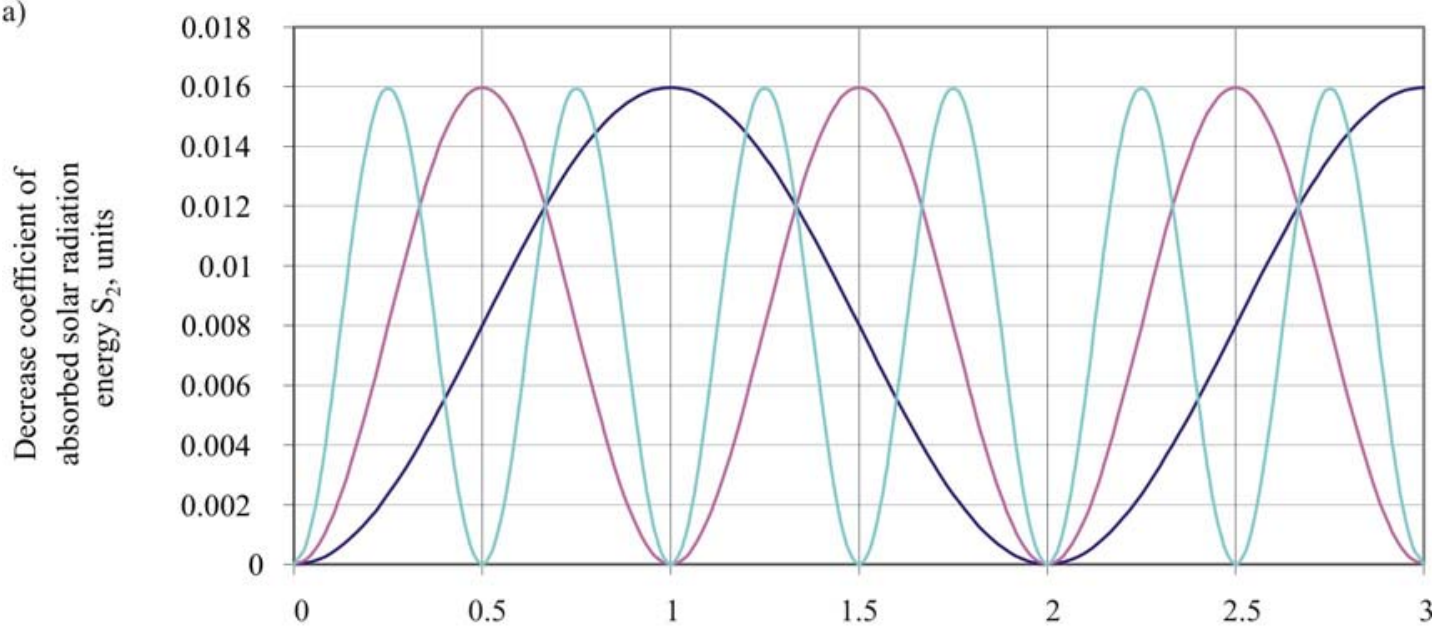

Time, $\mathrm{s}$

Plant leaf oscillation frequency, $\mathrm{s}^{-1} \quad-0.5 ; \quad-1 ; \quad-2$

b)

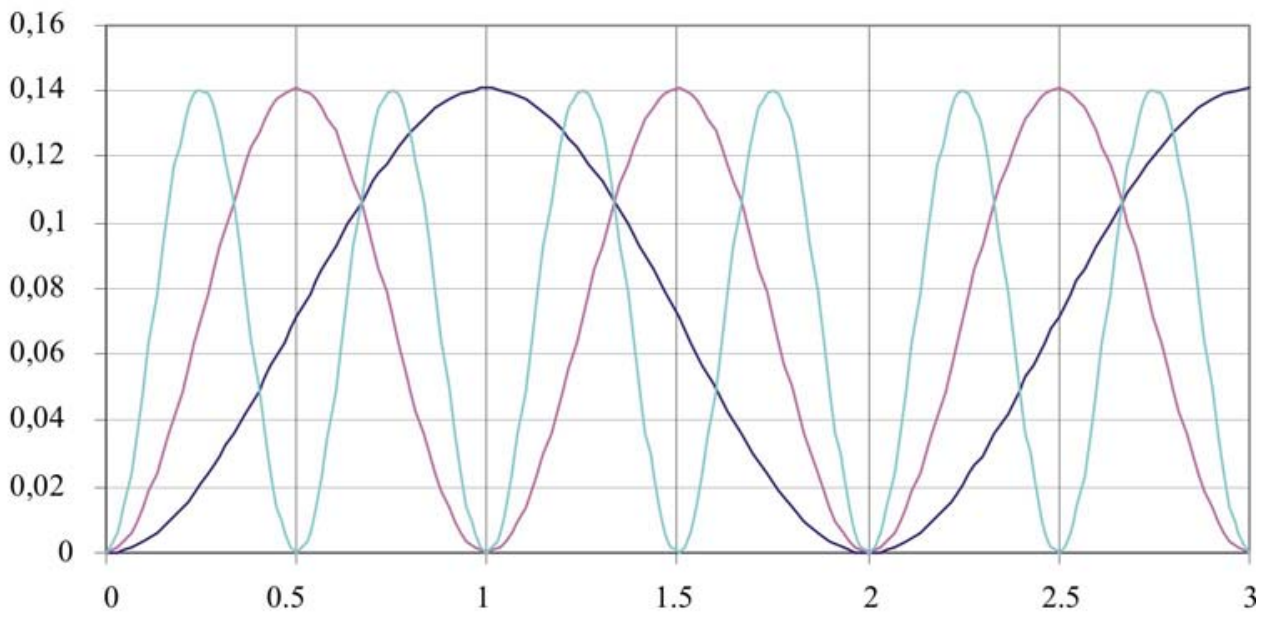

Time, $\mathrm{s}$

Plant leaf oscillation frequency, $\mathrm{s}^{-1}$

0.5 ;

1 ; 2

Fig. 5. Dependence of the decrease coefficient of the absorbed solar radiation energy $S_{2}$ on time during periodic change of the leaf position angle $\beta$ when the plant leaf oscillation amplitudes: $\mathrm{a}-\beta_{A}=10^{\circ}, \mathrm{b}-\beta_{A}=30^{\circ}$

\section{Conclusions}

1. When the plant leaf is in the edge positions of angles $10^{\circ}, 20^{\circ}$ and $30^{\circ}$ with respect to the Sun, $1.5 \% ; 6 \%$ and $13 \%$ less of radiation energy reach the leaf, respectively.

2. During periodic oscillation when the plant leaf oscillation is not bigger than $10^{\circ}$, up to $1.6 \%$ less of the Sun's radiation energy reach the leaf surface in a certain period of time, and at the oscillation amplitude of up to $30^{\circ}$ up to $14 \%$ less of the Sun's radiation energy access the leaf surface.

3. The total amount of solar energy received during pulsations of the Sun's radiation energy is not dependent on the frequency of oscillation in the same interval of time.

4. When the plant leaf changes its position with respect to the Sun under natural conditions (e.g. because of the wind effect), temperature pulsations, caused by the Sun's radiation energy pulsations, start in the leaf.

\section{References}

Brown, H. T.; Escombe, F. 1905. Researches on some of the proceses of green leaves, in Proc. of the Royal Society. London, series B, 76, No 507, 92-118.

Čèsna, J.; Sirvydas, A.; Kerpauskas, P.; Stepanas, A. 2000. Šiluminių energijos procesų, vykstančių terminiame peilyje ir jo aplinkoje, naikinant piktžoles tyrimas, Aplinkos inžinerija [Environmental Engineering] 8(1): 3-7.

Fitter, A.; Hay, R. 2002. Environmental physiology of Plants. S.D., S.F., N.Y., B., L., S., T., Academic press. 367 p.

Hayashi, H. 2001. Plant temperature stress. Encyklopedia of life sciences. John Wiley \& Sons, Ltd. All rights reserved. doi:10.1038/npg.els.0001320. 
Herve, C.; Lluis, C.; Xavier, L. R.; and Thierry, A. 2002. Unraveling the Effects of Plant Hydraulics on Stomatal Closure during Water Stress in Walnut, Plant Physiology 128: 282-290. doi:10.1104/pp.010400

Kajalavičius, A. 1992. Medienos hidroterminis apdirbimas ir konsevavimas. Vilnius: Mokslo ir enciklopedijų leidykla. $323 \mathrm{p}$.

Kerpauskas, P.; Sirvydas, A.; Lazauskas, P.; Vasinauskiene, R.; Tamosiunas, A. 2006. Possibilities of Weed control by water steam, Agronomy Research 4: 221-255.

Lafta, A. M.; Lorenzen, J. H. 1995. Effect of high temperature on plant growth and carbohydrate metabolism in potašo, Plant Physiol. 109(2): 637-643.

Ruseckas, J. 2002. Miško ir drégmès sqveika. Kaunas: Latutè. $200 \mathrm{p}$.

Sirvydas, A. P.; Kerpauskas, P.; Vasinauskienė, R.; Nadzeikiené, J.; Čekanauskas, S. 2006. Analysis of the thermal weed extermination processes: devices and their theoretical validation, Development of Agricultural Technologies and Technical Means in Ecological and Energetic Aspects. EurAgEng. 11: 332-344.
Sirvydas, A.; Čèsna, J.; Kerpauskas, P.; Vasinauskienė, R. 2000. Piktžoliu terminio naikinimo aukštatemperatūrèje aplinkoje tyrimai, Aplinkos inžinerija [Environmental Engineering] 8(1): 28-37.

Sirvydas, A.; Kerpauskas, P. 2006. Energiniu procesu agrofito aplinkoje aspektai, Energetika 4: 9-15.

Sirvydas, A.; Lazauskas, P.; Stepanas, A.; Nadzeikienė, J.; Kerpauskas, P. 2006. Plant temperature variation in the thermal weed control process, Journal of Plant Diseases and Protection 20: 355-361.

Šlapakauskas, V. 2006. Augalı ekofiziologija. Kaunas: Latutė. $413 \mathrm{p}$.

Šlapakauskas, V.; Duchovskis, P. 2008. Augalu produktyvumas. Klaipèda: IDP Solutions. 253 p.

Stašauskaitè, S. 1995. Augalu vystymosi fiziologija. Vilnius: Mintis. 226 p.

Venslauskas, M. 1996. Biofizika. Kaunas: KMA leidykla. 207p.

Ількун, Г. М. 1967. Енергетичний баланс рослин. Киев. 234 c.

\section{SAULE்S SPINDULIUOTE்S ENERGIJOS PULSACIJOS AUGALO LAPE}

\section{A. Sirvydas, V. Kučinskas, P. Kerpauskas, J. Nadzeikienė, A. Kusta}

\section{Santrauka}

Saulès spinduliuotès energija būtina augalijai, kuri lemia biosferos egzistavimą. Augalas $1-2 \%$ absorbuotos spinduliuotès energijos sunaudoja fotosintezei, o 99-98 \% absorbuotos energijos augalo lape virsta šilumine energija. Natūraliomis aplinkos sąlygomis esant mažiausiam vejjui augalo lapu padètis Saulès atžvilgiu keičiasi. Taigi augalo svyruojančio lapo gaunamas Saulès spinduliuotès energijos kiekis yra kintamas, tai sukelia pokyčius augalo lapo energijų balanse ir kintamą šilumos išsiskyrimą lape. Analizuojant Saulès spinduliuotès energijos pulsacijas augalo lape, nustatyta, kad, lapui esant kraštinèse $10^{\circ}, 20^{\circ}$ ir $30^{\circ}$ kampu padètyse Saulès atžvilgiu, i ji atitinkamai patenka 1,5 \%; 6 \% ir $13 \%$ mažiau spinduliuotės energijos. Augalo lapui periodiškai svyruojant, kai svyravimo amplitudè yra iki $10^{\circ}$, per tam tikrą laiką i lapo paviršių patenka iki 1,6 \% mažiau Saulès spinduliuotès energijos, o kai svyravimo amplitudè siekia iki $30^{\circ}$, - iki $14 \%$ mažiau. Saulès spinduliuotès energijos pulsacijų metu gautas bendras spinduliuotès energijos kiekis nepriklauso nuo to paties laiko intervalo svyravimo dažnio. Dèl Saulès spinduliuotės energijos pulsacijų, natūraliai keičiantis augalo lapo padèčiai Saulès atžvilgiu, lape kyla temperatūros pulsacijos.

Reikšminiai žodžiai: Saulès energija, energijos srautas, augalo lapas, energijos balansas, pulsacijos, svyravimo dažnis, lapo temperatūra.

\section{ПУЛЬСАЦИИ СОЛНЕЧНОЙ ЛУЧЕВОЙ ЭНЕРГИИ В ЛИСТЕ РАСТЕНИЯ}

\section{А. Сирвидас, В. Кучинскас, П. Керпаускас, Ю. Надзейкене, А. Куста}

\section{Резюме}

Растения потребляют солнечную лучевую энергию, которая является основой существования биосферы. 1-2\% абсорбированной лучевой энергии они используют на фотосинтез. В натуральных условиях при малейшем дуновении ветра листья растений меняют свое положение относительно Солнца. Колеблющийся лист получает переменное количество лучевой энергии, которое вызывает изменения в энергетическом балансе листа растения, что сказывается на переменном выделении тепла в листе. Анализируя пульсации солнечной лучевой энергии в листе растения, установлено, что при крайних положениях листа относительно Солнца на 10, 20 и 30 градусов на лист попадает соответственно на 1,5\%, 6\% и 13\% меньше лучевой энергии. При периодическом колебании листа, когда амплитуда его колебания составляет 10 градусов, за известный промежуток времени солнечная лучевая энергия, попадающая на поверхность листа, уменьшается до 1,6\%, а при амплитуде колебания до 30 градусов соответственно количество лучевой энергии на поверхности листа растения уменьшается до $14 \%$. Установлено, что суммарное количество солнечной лучевой энергии во время пульсации не зависит от частоты колебания листа за одинаковый промежуток времени. Пульсации солнечной лучевой энергии при изменении положения листа растения относительно Солнца вызывают температурные пульсации в листе.

Ключевые слова: солнечная энергия, поток энергии, лист растения, энергетический баланс, пульсации, частота колебаний, температура листа. 
Algimantas SIRVYDAS. Prof. Dr Habil of Science (agriculture and environment engineering), LŽŪU, 1993. Doctor of Science, Vilnius University, 1961. Publications: author of 17 educational books, over 200 scientific publications. Membership: a corresponding member of International Academy of Ecological and Life Protection Sciences. Research interests: energy processes in plants and environment, thermal weed control equipment and theoretical validation, modeling energy processes in plants.

Vidmantas KUČINSKAS. Board of directors of ISC “Arvi and co”. Engineer, KTU, 1985. Research interests: environment protection, energy processes in environment, renewable energetics.

Paulius KERPAUSKAS. Dr, Assoc. Prof., Dept of Heat and Biotechnology Engineering, Lithuanian University of Agriculture (LŽŪU). Doctor of Science (mechanical engineering), LŽŪU, 2003. Publications: author of 2 educational books, over 50 scientific publications. Research interests: energy processes in plants and environment, thermal weed control equipment and theoretical validation, modeling energy processes in plants.

Jūratė NADZEIKIENĖ. Dr, Dept of Occupational Safety and Engineering Management, Lithuanian University of Agriculture (LŽUU). Doctor of Science (environmental engineering and landscape management), LUŽU, 2005, Master of Science (material engineering), KTU, 1998. Publications: author of over 13 research papers, 2 methodological books. Research interests: environmental safety, environmental protection, modeling of heat transfer processes.

Albinas KUSTA. Dr Habil, Prof., Dept of Hydraulic Engineering, Lithuanian University of Agriculture (LŽŪU). Doctor Habil of Science (agriculture and environment engineering), LŽŪU, 1988. Doctor of Science, 1968. Membership: a corresponding member of Lithuanian Academy of Sciences. Publications: author of over 120 scientific publications. Research interests: environment engineering and landscape management. 